\title{
Sovereignty and Economy According to Montchrestien and Cantillon ${ }^{1}$
}

\section{Jérôme Maucourant*}

\section{Summary}

The political constitution of markets is promoted by Montchrestien whereas, on the contrary, the absolute autonomy of the sphere of exchange is favoured by Cantillon. Yet, this article seeks to demonstrate that both authors also participate in the emergence of a modern way of thinking about the economy. In both cases, we find the idea that the sphere of exchange acquires an autonomy which requires the application of a specific science. In the case of Cantillon, this autonomy is absolute and anticipates the foundations of contemporary economics. On the other hand, Montchrestien's work forms part of a "political economy". This article also aims to show that the mercantilism attributed to Montchrestien in no way implies that, in principle, the economy when theorised as such is a simple transposition of a war-like model. Similarly, it will seek to show that Cantillon, a supposed mercantilist, does not suggest that state intervention is futile, even if he adheres to the fundamental principles of economic liberalism. This modernity has two sides, represented by these texts which present economics as a science for the first time. It will be suggested that it allows us to call into question the postmodern theses which imagine a contemporary economic world in which the classical notion of sovereignty is totally absent.

Keywords: sovereignty, political economy, money, Montchrestien, Cantillon, modernity, liberalism, trade, exchange, markets, selfregulation, auto-constitution of society

JEL: B11, B31

\section{Introduction}

The different modernities of

Montchrestien and Cantillon

Given that modernity is such a make it clear that, for us, the term refers to the point in Western civilisation when, from the $16^{\text {th }}$ Century onwards, politics, religion and economics progressively came to be regarded as separate categories. Modernity was formed at the end of the $18^{\text {th }}$ Century, following the 'dual revolution' in Europe (to borrow Hobsbawm's phrase), comprising both the French political revolution and the British Industrial Revolution. This process has taken a number of different directions:

\footnotetext{
${ }^{1}$ I thanks Alain Guéry (CNRS, France) for his very valuable comments. This paper was discussed during a session of the seminal seminar "Dons, monnaies, prélèvements ", Centre de Recherches historiques (EHESS, France), that was animated during many years by Alain Guéry (https://journals.openedition.org/annuaire-ehess/19685 ). A first form of this paper was translated by Pr. Emma Bell (Université de Savoie, France), but I am entirely responsible for any remaining errors in this paper. The translation of French texts into English is either our own or has been reviewed by ourselves. We have chosen to translate Montchrestien's and Cantillon's writing using contemporary English syntax and orthography

"Université Jean Monnet (Saint-Etienne, France) and Laboratoire Triangle UMR 5206 (https://sihe.hypotheses.org/).
} 


\section{Articles}

whereas Cantillon's Essai forms part of the prolegomena of liberal thought in economics, almost a century before, Montchrestien's Traicté $^{3}$ heralds a conception of economics which reveals another facet of modernity. For Montchrestien, modernity holds that religion, as a stimulus for moral standards, finds itself assigned to a subordinate role in social life. In order to avoid the disintegration of the social body, politics must embed economic activity, the autonomy of which is fundamentally relative. Such a line of thinking presupposes a hint of autonomy between what now appear to be obviously separate dimensions of social life - religion, economics and politics - without implying that society develops by itself ${ }^{4}$ or that the economy functions autonomously. We are indeed led to speak of the 'economy' and of 'politics' separately with Montchrestien in order to elucidate the concepts which make sense for the contemporary reader ${ }^{5}$. Without doubt, this exercise in conceptual distinction between economics and politics is less daring with regard to Cantillon's work.

Our hypothesis is that the 17th Century marks a rupture in the process of the development of modernity. This does not however mean that we think that these two works reflect the changing situation in Western economies, characterised by the growth of market regulations. Actually, the development of the beginning of a system of markets ${ }^{6}$ is the unexpected result of more modest policies
Sovereignty and Economy According

to Montchrestien and Cantillon

promoted by authors such as Montchrestien. Indeed, promoting commercial links was by no means the equivalent of the self-regulating market $^{7}$. Similarly, the theoretical work of Cantillon, in the image of those who one began to call "economists" at the end of the $18^{\text {th }}$ Century, aims to isolate a particular kind of exchange, the economic exchange, as the foundation of a new social order ${ }^{8}$. It is in the context of these hypotheses that we will show that Montchrestien elaborates a deeply political way of thinking about the economy as an emerging facet of social life. He marks a rupture with ancient and medieval thought according to which the economy was deeply anchored in other ideological elements and social relations.

We will nevertheless show how the modernity of Montchrestien's comments contrasts with the beginning of the liberal modernity which is embodied by Cantillon. In this way, we hope to show that even if the progressive distinction between what we today call economics, politics and religion is a necessary condition of all modern thought, there is absolutely no reason why the movement of aspects of social life towards absolute autonomy should constitute the key to modernity. The moment of Western intellectual life inaugurated by Montchrestien is still relevant because the question of the emancipation of the economy from society will always be posed, rightly or wrongly. Moreover,

\footnotetext{
${ }^{2}$ Essay on the Nature of Trade in General, c. 1730.

3 Treatise of Political Economy, c. 1615.

${ }^{4}$ Deleule (2001, p. 20-21) reminds us that if Anglo-Scottish empiricism, as exemplified by Hume, effectively entails the idea that society develops autonomously, this does not mean that it follows economic determinism.

${ }^{5}$ The apparent arbitrariness of these distinctions is tempered by the fact that these concepts are the fruit of the period in which modernity developed. It goes without saying that Montchrestien never used these terms, given that they were only invented in the 19th Century. Nonetheless, in order to understand the meaning of historical texts, one cannot avoid using words and descriptions that are not those of the 17th Century: a totally contextual reading is impossible.

${ }^{6}$ The opposition between market and markets is central. With regard to the study of exchange practices of the Ancien Régime, Guéry (2003, p. 1), writes, "Markets appear in different forms but it is difficult, even foolish, to consider them as forms of the market or even of a market unique to societies at this time" (author's italics).

7 According to Polanyi's concept (1944, p. 68).

${ }^{8}$ Guéry (2005a, p. 37).
} 


\section{Articles}

one should not be surprised that we invoke other authors, such as Polanyi or Negri, whose preoccupations concern the world today: it seems preferable for us to explain what, in the contemporary context, arouses our interest in historical texts. Thus, before saying that the crisis of modernity gave birth to postmodernity, is it not important to understand what led to modernity in the first place? In this respect, a reading of Montchrestien and Cantillon is an interesting exercise which can have the advantage of encouraging a more rigorous approach to a discussion in which all kinds of confusions and approximations are common.

In the first part (General Anthropology or Economic Anthropology), we will outline the hypothesis according to which the keystone of Montchrestien's work is non-contractualist anthropology which places the monarch, this distinctive imago dei, at the centre of the social sphere. Good government can only be exercised by the monarch who is necessary to the social order because he understands the foundations of human nature and knows how to lead the people. On the contrary, Cantillon's portrayal of human nature belongs to an anthropology which is no longer 'general' but 'economic', typical of liberal modernity. The second part (The Economy: Instituted Process or Self-Regulating Market?) explains Montchrestien's conception of the economy according to which there are three kinds of exchange which structure the sphere of commerce. Pure economic exchange does not appear as such in the sense that the social nature of exchange is still apparent. In the third part (Political Economy or Commerce in General), we will show how Montchrestien demonstrates that this knowledge of human nature can be used to promote the wealth of the people and the power of the monarch: thus is explained the necessary return of the monarch to the economic sphere which, without him, is dysfunctional ("détraquée"). In this discourse, there is no principle of the self-regulating market as a mechanism for the distribution of resources. Instead, there is a set of principles which are meant to regulate the volume of exchange, to protect the production of the Kingdom and to educate men. This does not mean that Montchrestien had no notion of the benefits that could be made from exchange. On the contrary, Cantillon's model rests on a purely economic conception of exchange. In the fourth part ('Mercantilism', Commerce and Money), we will show that, for Montchrestien, the monetary question is subordinate to other questions. This is something which may surprise us, coming from the pen of a 'mercantilist', and forces us to reexamine somewhat this concept which is also developed by Cantillon. The conclusion (Modernities in the Traicté and the Essai) returns to a theme which has structured our argument: to what extent can it be said that Montchrestien's political economy ${ }^{9}$ is in any sense modern? Indeed, for the most part, political economy does not herald contemporary economics, as is shown by the comparison made with the work of Cantillon who, on the contrary, proposes a pure economic paradigm. But this does not in any way mean that Montchrestien's text reveals conceptions that are definitively outdated because economics, in its most scholarly guise, aims to understand political, institutional and cultural phenomena. Yet it is clear that the reduction of politics or of institutions to a ruse of economic reason is not totally persuasive.

\footnotetext{
${ }^{9}$ According to the New Palgrave Dictionary of Economics Online, the term 'political economy' or 'œconomie politique', as used by Montchrestien, "signified an attempt to extend the art of estate management to the entire kingdom of Louis XIII and his successors. This usage, generalised to mean a 'system' of policy designed to 'increase the riches and power' of a country remained current until the end of the 18th Century".
} 


\section{Articles}

It goes without saying that Cantillon's work, which heralds (our) economic modernity, is marked by its context. The arguments of this author are mixed with more traditional elements that the concept of 'mercantilism' partly incorporates. It is nonetheless possible, via a comparative approach to these two authors, to make a contrast which highlights the changes that the $17^{\text {th }}$ Century involved in Europe and the contradictory aspects of modernity in economics ${ }^{10}$.

\section{General Anthropology or Economic Anthropology?}

The Traicté can be disconcerting for a contemporary reader because it takes the form of written advice given to the King of France in order to enable him to elaborate the procedures of 'good government'. This kind of essay is a classic topos, common to societies of the Ancien Régime. Thus, without doubt, Montchrestien's book does not contain an economic theory in the contemporary sense of the word. It constitutes more of a doctrine which outlines a set of principles. It does not make the distinction between normative and positive registers which is familiar to contemporary theoretical systems. Yet, this does not prevent the author from developing a coherent conception of politics as an art supported by an anthropology which is understood as a commentary on human nature. According to Montchrestien (1615), politics is the government of the Common Weal. He supports the idea of natural sociability because his portrayal of man as a social animal comes to him from Aristotle (p. 57). This point is important because it implies that the science of 'public householding' or even of
Sovereignty and Economy According

to Montchrestien and Cantillon

'political economy' is the product of a general anthropology rejected by orthodox economists today. The Aristotelian thesis taken up by the author should not surprise us: it was only in the middle of the $17^{\text {th }}$ Century that theories of the social contract were really developed ${ }^{11}$. Far from taking a contractualist view of the political foundation of society, Montchrestien considered that man was reasonable to the extent that "he sometimes embraces public service with a passionate desire [...] In this way, often reserving the smallest part of his life for himself, he voluntarily dedicates the greatest and best part of his life to the service of others". In other words, it is by the very exercise of his reason that man manages to reconcile his private and collective interests.

What we will from now on call the 'social division of labour' is considered as another important form of social 'cement' by Montchrestien. This is why, despite how his work may appear on the surface, Montchrestien cannot be considered to follow Aristotle. He disagrees with the vita activa of the Ancients as well as the vita contemplative of the Middle Ages, favouring a healthy vita activa of a new and particular kind, characterised by the importance given to industry over political action $^{12}$. For Montchrestien, a vita activa is a wholly economic way of life, politics being the reserve of the monarch and not of his subjects. Here we are far from the ancient model in which the precondition of freedom is being able to live off the work of others thanks to one's membership of the political community. This is why it is necessary to analyse the criticism that the author makes of "contemplative life" (p. 56) which being "the closest to God" is pointless without action.

\footnotetext{
${ }^{10}$ Descimon et Guéry (1989, p. 211) suggest that even if there is no "political modernity of Modern Time", this may be because the Bourbon monarchy was driven by a "conscious desire to resist modernity" and that the contradiction between "total royal power" and the "privilege" of royal subjects (p. 212 sq.) is not what characterised political modernity.

11 These social contract theories were only really seriously questioned by Hume in the 18th Century. See Gautier (1993, p. 46).

12 We are here using Arendt's terminology (1958).
} 


\section{Articles}

It would certainly be difficult to justify 'occupation' or 'action' in pre-Weberian terms, as François Billacois would have us believe in the introduction to his edition of the Traicté: the fact that Montchrestien ( $p$. 57) claims that it is sufficient to contemplate "the works of God" on the Seventh Day is not proof of Protestantism but a simple sign that divine commandment is the condition of the wealth of the people and, consequently, of kings. In other words, there is nothing in that which could be considered to be proof of heresy by Catholics of his time $^{13}$. On the contrary, Cantillon (p. 53), after having lambasted the unproductive role of the monks, enquires into the economic consequences of the Reformation, explaining that "States which have embraced (Protestantism) have become visibly more powerful" because Catholics have numerous religious holidays. Nonetheless, both authors reject the primacy of contemplative life over other ways of life. In this sense, Cantillon and Montchrestien say the same thing with regard to the relationship which should be established between economy and religion, from the viewpoint of the quest for wealth and the power of the State.

Unlike Cantillon, Montchrestien's general depiction of society is strongly characterised by a priori which reveal religious transcendence. He points out that royal authority derives from the "supreme power of God" (p. 43). Yet he also claims that this power should only be exercised in the interest of the "Common Weal" and that the power of religion must be subordinated to that of the sovereign: "It is a great tool in the hands of he who knows how to use it correctly" (p. 224). Natural sociability must not be corrupted by a false interpretation of religious texts. Consequently, one part of his programme of political economy states, "From there, it follows that the most important role of the State is to prevent any part of it from becoming useless" (p. 58). Montchrestien goes as far as to suggest that economic sanctions should be used to control the activities of the clerics. He explains that since ecclesiastical privileges are granted by the monarch, it is his responsibility to ensure that they are not abused (p. 227). As a good Gallican, he reminds us, "Always remember that the Church is in the State, not the State in the Church" (p. 228).

If the clerics must then be the instruments of the monarch, the people, and particularly those who make up the "Labourers", must be the focus of the practice of good government. The kingdom is composed of "three principal orders: clerics, nobles and commoners" (p. 46). Justice is a kind of "cement" which "sticks" these three orders together. Montchrestien divides the "order of commoners" into Labourers, Craftsmen and Merchants (p. 46-7). The King, allowing laws to be properly applied, thus transforms the "multitude" (p. 267) into a social body. This in no way means that the powers of the police or the administration of justice result from the arbitrary power of the King. On the contrary, Montchrestien deplores the existence of too many laws, citing the example of Julius Cesar who "intended to limit the civil law to a few principles" (p. 277). He is also concerned

\footnotetext{
${ }_{13}$ Perrot (1992, p. 64), who takes Montchrestien's thought seriously, places it in the context of a civilising process in which the emphasis is placed on "the refusal of Christian economy according to moral theology, work as punishment, just price and idleness of capital". The origin of such a refusal seems to result from the dislocations caused by "the progress of Nation-States since the $15^{\text {th }}$ Century, the Renaissance and the Protestant Reformation". Perrot's proposition has the advantage of highlighting the numerous factors contributing to the creation of a new way of presenting the economy (even if the Reformation may be seen rather as a consequence of this civilising process than as the cause of economic transformation). Nonetheless, it does not seem that Montchrestien buries the question of just price in favour of an implicit thesis of the auto-constitution of the economy. On the contrary, the monarch, as the wise architect of the social sphere, is the one who regulates economic fluctuations in quantities and in prices thanks to his good administration.
} 


\section{Articles}

about the poor quality of the judges, which undermines royal authority. In addition, he reminds the King that even if God elected him as his "Lieutenant on Earth"14, nonetheless "you must ensure that his will is done" ( $p$. 272).

Yet, the venality of office goes against the very will of God who wishes "justice to be properly delivered to your People by each Magistrate" (idem). Indeed, he writes, "You must therefore look for and invent all legitimate means in order to wipe out the venality of public office [...] The ambition of honours means that those which are put up for sale find many buyers unworthy of owning what they purchase" (p. 274). This is why he cites Henry VIII as an example. He reportedly only granted public office to those who did not ask for such honours and who were highly knowledgeable in "Theology" and "Jurisprudence" (p. 266). The venality of office is a source of injustice which is a danger to the social order. Worse, when justice, an important branch of "public affairs", becomes the object of "avarice", it must rightly be suspected of "lengthening trials" (p. 278); some "instruct", others "summon", and others finally "adjudicate on the case". Nonetheless, venality alone is not responsible for the creation of this gold digging process that the exercise of justice is becoming. Montchrestien also denounces the rise of judge-made law whilst magistrates ought to be bound to be made to "judge according to laws and ordinances without in any way being able to stray from them under whatever pretext. Laws must control magistrates, not the other way around" (p. 277). Against this confusion of public and private interest, Montchrestien asserts, "there is no vice more dangerous than greed amongst those who handle public affairs" (p. 278). This proves the
Sovereignty and Economy According

to Montchrestien and Cantillon

extent to which public action differs in nature from private conduct.

The image of the monarch, concerned for the well-being of his people, limiting the abuse of judicial power and controlling the clerics, finds its greatest expression in the reciprocity which must be forged between the people and the monarch: "Whosoever is called to govern the people must love them in order to be loved himself because their love is his strongest defence, his unassailable fortress" (p. 80-1). As the strength of royal power resides in the very love the sovereign has for his subjects, we have gone beyond the necessary royal benevolence that Montchrestien evokes elsewhere (p. 80). This entails a classical anthropological model which may be refined by studying more closely the role of God who, looking over us, is the vigilant master of this reciprocity. But, if proof of the benefaction of the monarch is his munificence, the good King being he who knows how to give, Montchrestien takes care, as the master of public householding, to remind the King of the need to exercise distributive justice, notably with regard to the attribution of such costly honours. He explains that the monarch must remember that it is "the pure blood of your people which deserves to be used for good, useful and honest ends" (p. 259). Indeed, the author fears that the munificence of the monarch conflicts with the good practice of governance when it is monopolised by the nobility (p. 260).

According to Montchrestien, the final important characteristic of good government is "Censure". This term covers two ideas which are strongly linked, as was already the case for the Roman census which combined an evaluation of one's wealth and of one's moral qualities ${ }^{15}$. Montchrestien favours a return to the past in this respect and even

\footnotetext{
${ }^{14}$ This means that the King takes the place of God on Earth.

${ }^{15}$ See Andreau (1998, p. 215 and p. 250).
} 


\section{Articles}

asserts, "From the moment the Roman Empire stopped using the census, it headed straight for decline" (p. 233). Montchrestien suggests going even further in this return to Antiquity, suggesting not only a return to the original "liturgies" (p. 237) ${ }^{16}$ but also to another old Athenian legal practice which allowed trials to be brought in order to prove that other citizens could better afford to fulfill their liturgical duties $^{17}$. Montchrestien is convinced that knowledge of the true wealth of some citizens or, on the contrary, of the genuine poverty of others, is an effective guarantee of political stability.

Nonetheless, the use of Roman, or sometimes even Hellenist rhetoric, common under the Ancien Régime, can mask the fundamental modernity of Montchrestien's writing. The Roman model of public virtue is magnified by the example of Tribune Drusus "who wanted to make holes in his house so that everyone could see inside" (p. 236). This would at first appear to be an example of freedom in the ancient sense of the term, far removed from the "freedom of the Moderns". Yet, this powerful image, when placed in the general economy of the Traicté, aims to show that those who have nothing to hide concerning the real source of their wealth have nothing to worry about. For Montchrestien, good merchants have nothing to fear from public judgment. In other words, his treatise is not a real exaltation of the "Freedom of the Ancients" in the sense that these words would have had for Constant: it rather involves the development of a social and political model which legitimates itself by a very selective reading of ancient Greco-Roman or biblical texts.

There is consequently a huge gulf between Montchrestien and the other unmistakably modern authors of the following century, such as Hume, who were the true architects of a genuine economic anthropology. Our hypothesis is that Cantillon is one of these architects, explaining the unexpected and sometimes harmful consequences for society of the conflict of interests motivated by economic considerations. From this point of view, numerous contemporary economists are not any more modern, following the wanderings of the invisible hand. Liberal modernity should not be reduced to the pure fantasy of the economic self-regulation of society. Indeed, placing homo economicus at the heart of this discourse does not mean systematically rejecting the benefits of certain political actions. In this respect, the mercantilist dimension of Cantillon's work expresses an aspect of the classical liberal problem of justifying certain selective forms of state intervention.

Consequently, instead of ordering society around this sovereign figure of a privileged imago dei, Cantillon removes all traces of religious transcendence in the formation of social relations. Politics becomes an economic technique of governing men. What remains of sovereignty can be glimpsed at in a passage in which Cantillon, assuming that "land belongs to no one in particular", and then showing all the difficulties that this engenders, claims, "it would always be necessary to fall back upon a law to settle ownership in order to establish a society, whether the law rested upon force or upon policy" (p. 4). Does there exist the slightest link with sovereignty as "the absolute and eternal power of a Common Weal", as defined by Bodin who had a considerable influence over Montchrestien? Does the idea of sovereignty not dissolve into a simple demand for 'government' which a society of

\footnotetext{
${ }^{16}$ In classical Athens, the institution of liturgies obliged wealthy citizens to fulfill a number of civic duties, such as arming a warship etc.

${ }^{17}$ However, this practice led to the growth of the legal procedures that Montchrestien deplores elsewhere.
} 


\section{Articles}

propertied people accepts to freely delegate according to their interests?

The contrast between Cantillon and Montchrestien is striking. For Cantillon, social life frees itself from all religious transcendence. The social division of labour regulates itself according to the procedures of a society conditioned by the profits of merchants. There consequently emerges an equilibrium ${ }^{18}$ resulting from the game of profitability relative to investments (p. 29 sq.). It would thus be possible, despite the "considerable" place given to the market in Cantillon's work, to show that the market "can never create efficient mechanisms of price gravitation or stable equilibrium", as Grenier has written (1996, p. 34), explaining that "market 'imperfection' is considerable in Cantillon's work". If what we mean by 'efficiency' is what the general equilibrium theory has taught us, this claim is undoubtedly correct. Nevertheless, from the Austrian point of view of the "tendency towards equilibrium"19, it is possible to assert with certitude that the efficiency of the market is a process for Cantillon, the role of entrepreneurs being crucial for the proper application of a trend which never reaches its aim.

Most importantly, Cantillon makes no mention of the possible benevolence of social actors who are basically regarded as economic actors. Thus, there is no basic need for a king
Sovereignty and Economy According

to Montchrestien and Cantillon

beyond the necessity to have the rules of society respected: "It is need and necessity which enable farmers, craftsmen of every kind, merchants, officers, soldiers, sailors, domestic servants and all the other classes who work or are employed in the country, to exist. All these working people serve not only the King and the landowners but each other" On the contrary, for Montchrestien, the charity of the monarch is necessary in order to govern the social community. For him, the "ecclesiastical state" is not the principal component of the social order. Religion is only a "tool" to be used by the King of France, just as Censure is important for Montchrestien because the foundation of natural sociability is indeed morality. It is the role of the monarch to remind men of their innate kindness. The monarch should show them the example which should serve as social glue for the political order. The chapter entitled, Of Exemplarity and the King's Main Concerns (p. 213), is particularly illustrative of this concern. The author even claims that the monarch "exists for his people" (p. 221), who "represents and moderates the body politic" (our italics) and should make use of the desire for imitation that resides within each one of us for the good of the social order as a whole (p. 217-8).

Following the general current of thought at the time, Montchrestien also invokes

\footnotetext{
${ }^{18}$ It would be an exaggeration to make Cantillon the precursor of this issue. It should not be forgotten that our task only aims to highlight several aspects of modernity in economics which emerged between the beginning of the $17^{\text {th }}$ Century and the beginning of the $18^{\text {th }}$ Century. The work of Montchrestien and Cantillon necessarily has the rather arbitrary purpose of marking out the key issues. Kubeta (1941, p. 81) has analysed the concept of equilibrium with Boisguilbert. Even more than Cantillon or Montchrestien, according to Mac Donald (1966, p. 109), he anticipated a truly macroeconomic representation. Similarly, Billoret, (1989, p. 69) does not hesitate to claim that the "natural" equilibrium of Boisguilbert is "Walrasien". To this end, he invokes the work of Clower who holds that the "constraints" weighing on exchange would reveal the Keynesian conclusions that Boisguilbert had anticipated. In general, we disagree with the excesses of the retrospective history of ideas, as followed by Billoret when he attributes an "economic analysis" founded on the notions of "utility" and "marginal utility" to Aristotle. But it is true that it is no longer necessary to invoke general anthropology in order to understand Boisguilbert and Cantillon.

19 See Kirzner (1973), a great supporter of the entrepreneur as the keystone to the tendency towards equilibrium. He seeks to show the path which could eventually lead to equilibrium, thanks to the entrepreneur who is always "alert" to the opportunities for profit that are "waiting to be noticed" (p. 74).
} 


\section{Articles}

the figure of the monarch as image of God or image of Christ $^{20}$, thus reinforcing the importance given to the function of representation unique to the King: "Though all men are divine creatures [...] kings are separate from the rank of commoners. As the true children of God, they have more divine characteristics and lineaments. Thus they are to this Eternal Divinity what shadow is to the body, the image to the thing" (our italics, (p. 215)). Moreover, this passage may, strictly speaking, pose a theological problem, given that Christianity states that every man is imago dei. In addition, the King should, following the same theological-political line of interpretation, only incarnate immortal judicial power $^{21}$. Yet, in emphasising the fact that the King is "separate from the commoners", being the only perfect image of God, Montchrestien upsets the theologico-political treatise of the "king's two bodies" which, for the Christian, remains a way of reconciling faith in Christ and the acceptance of political power. If Montchrestien affirms with such conviction that kings are the "true children of God", it is without doubt in order to justify a monarchial absolutism considered necessary to avoid ever returning to what the kingdom was like during the wars of religion.

For Montchrestien, society is thus formed by moral ties, reinforced by good government which knows how to use man's inclination to imitate or emulate. Society is not born of the conflict between hedonistic individuals when faced with scarcity, as Cantillon would have us believe. For Montchrestien, there can be no concept of Market: markets only exist where merchants are subjected to government regulation. Montchrestien, reader of Aristotle, even if he does not mention his name here, considers that genuine scarcity is indeed that of honours, not of goods. The developments concerning the regeneration of Royal Orders (p. 230) are the consequence of this curious portrayal of the world because these orders, supported by proper censure, are the conditions of this exemplarity which is so essential to social stability. Contrary to Cantillon, the economic system according to Montchrestien is not the result of mercantile mechanisms which are supposed to be capable of producing basic economic order. It is this hypothesis that we shall explore further below.

\section{The Economy: Instituted Process or Self-Regulating Market?}

Contrary to Cantillon, whose work is more analytical and reveals a world which seems closer to our own, Montchrestien proposes a rather unique economy. The world he describes is not condemned to generally restrictive scarcity because men are numerous and their aptitude for work is excellent: only poor management can spoil this plenty which is the gift of $\mathrm{God}^{22}$. But beyond this singularity that liberal modernity might compare to archaism, the Traicté nevertheless plays a role in the creation of a modernity: "The plan to link domestic affairs (the economy) to the affairs of the State (politics) is new"23. The Traicté is not a relic which, if we are to follow many textbooks on the history of economic thought, is more suitable for citation than for study. Montchrestien is all too often known only for

\footnotetext{
20 See Kantorowicz (1957).

${ }_{21}$ This body of the king, the corpus mysticum, is immortal, in contrast to the other body of the king which is material and perishable.

${ }^{22}$ We are conscious that this feature of Montchrestien's thought, i. e. the place of gift in political economy, could be developed further in so far as the Treatise partly reflects sixteenth-century France in which gift has a very special place (Zemon Davis, 2000).

${ }^{23}$ Perrot (1992, p. 63).
} 


\section{Articles}

his invention of the widespread expression, political economy. Yet, this syntagm did of course have a precise conceptual meaning for its author ${ }^{24}$. Today, it would be generally incongruous to combine reflection on the scarcity of honours, competition between merchants and the nature of sovereignty. Contemporary ways of thinking do not immediately allow us to make sense of this treatise in which political, social and economic dimensions are so interlinked. Yet, are common definitions of economics, which rely on the concepts of scarcity and utility, not the reason why the Traicté is often misunderstood and ill-appreciated? Moreover, the triumph of liberal modernity the following century eclipsed authors such as Montchrestien, leading one to forget that liberalism is only one facet of modernity.

In order to better understand this world which is painted by Montchrestien, let us cautiously employ some of the contemporary categories that the Traicté helped to inspire. The sphere of the economy, which constitutes the investigative field of this work, refers to all the means and institutions essential to the very livelihood of man. Markets and money only have subordinate roles. This very conception of the economy implies an idea of politics as the art of linking the natural sociability of man to the principle of sovereignty. The result of the distinction made between economics and politics is that political economy, the science of the governance of man, allows the monarch to adopt the best means which aim to increase the wealth of his people and, thus, of himself. Consequently, Montchrestien
Sovereignty and Economy According

to Montchrestien and Cantillon

can be better understood thanks to the "substantive" conception according to which the economy is an "instituted process" 25 . This conception includes the question of social values, essential to ancient writers. Political economy is not rational knowledge of the allocation of scarce resources through the price system.

Cantillon presents the link between the economy and politics in a different way. He no longer accords the monarch an essential role in the process of the constitution of society, which is a partial result of a century of upheavals affecting the economic structure of society. The idea that the economy can be political vanished in favour of a reflection on "commerce in general". Following the explicit cost-benefit model, Cantillon (1755, p. 33) attempts to show that the monarch, owner of a large estate as if there were no other in the world", has every interest to off-load the cost of administering his estate, establishing market procedures which thus transform his "overseers" into "entrepreneurs" (p. 34). He thus shows that the structure of production adjusts itself to the variations of consumer via the system of the variation of market prices and the action of entrepreneurs (p. 35-36). The economy regulates itself and in this system the monarch becomes nothing more than a landowner who owns a larger estate than the others. How different to Montchrestien's world in which the monarch has an eminent role to play in the proper administration of markets! According to Cantillon, the economy can function very well without any intervention in its internal mechanisms no matter what

\footnotetext{
${ }^{24}$ To the best of our knowledge, the Traicté is the first text in which the expression political economy is used in the way it is commonly understood today, even if this expression had already been used by Louis Turquet de Mayerne in La Monarchie aristodémocratique, a text which appears to have been written in 1590 and published in 1611 (however, the meaning that Mayerne gives to this expression is different to that of Montchrestien).

${ }^{25}$ This is Polanyi's (1977, p. 25) idea according to which the "scarcity situation" is not universal because society can determine the means and ends of economic activity. The "substantive economy" relates to "interactions between man and his surroundings" (p. 31) and to the "institutionalisation of that process". In order for man's livelihood to be exposed to the fewest possible hazards (p. 34), it is necessary for collective behavioural rigidities to develop. In this way, the market is an "instituted process".
} 


\section{Articles}

principle of sovereignty is applied. It is the entrepreneurs' desire for profit which is at once the motor and the guarantee of economic stability which is hardly distinguishable from the social order.

The science of commerce in general is thus essentially different from political economy which aims to be a source of inspiration for "good government". Contrary to Cantillon, Montchrestien does not pretend to discover anything that has not already been discovered, the truth of the present finding its origins in a past which can forever serve as an example. Political economy often presents itself as an interpretation of texts even if it clearly does not limit itself to that. The reference made to Bodin is of key importance: certain passages of La République have even been reproduced exactly or only slightly modified. This is not decisive from our point of view. Starting from a criticism of the Ancients, as Bodin does, Montchrestien affirms that the Greeks and the Romans had not grasped the importance of the "regulatory function" of political economy: "All boils down to the fact that in the State (just as in the family), it is in the interests of all to govern men according to their own and particular inclinations [...] Contrary to the opinion of Aristotle and Xenephon, it can be asserted that the economy cannot be separated from government without destroying the Whole [...] They ignored the principle of public householding with which the responsibility of the State should be mainly concerned." (p. 67). It must nevertheless be admitted that if Bodin provides this fundamental insight, the Traicté cannot be reduced to that. Montchrestien explains the art of "public householding" and this is how political economy is invented. It refers to the idea that those in power are responsible for the welfare of men. Montchrestien takes Bodin's work further, and brings out the novelty of "public householding", rebuking Antiquity for its lack of reflection on the social division of work" as it exists in the towns: "Coming back to the Ancients [...], in their books we cannot even find any ordinances or guidelines on how to adapt men to states and train them for the liberal arts and trade, according to the capacity, temperament, utility and needs of each country" (p. 49). Montchrestien wants to be the conscious witness of new times; he distances himself from a number of his own previous claims according to which the Greco-Romans or the Hebrews are the source of truth.

We noted above the contrast between Cantillon's belief that the economy has the capacity to regulate itself and Montchrestien's general anthropology which suggests this is impossible. It would be incorrect to assert that a single pure economy exists in the Essai to the extent that the author himself provides a genuinely sociological dimension which is essential to his analysis. For instance, it is sufficient to recall his conjectural model of history which details the steps from a planned economy to a more efficient market economy which tends to balance itself. As an example of economic dynamics, the author invokes the fact that "entrepreneurs [...] always take as their model the lords and owners of the land. They imitate them in their clothing, meals and mode of life". Before such an idea had even developed, imitation as a key element of the sociology of the economy is present in his analysis. There is no fusion between social thought in general and that of the economy in particular but there is the idea that social constraints determine ultimate economic stability. This makes Cantillon a clear figure of modernity since socioeconomics do not, in principle, seek to deny the existence of pure economics, but to complement it.

\footnotetext{
${ }^{26}$ The term "division of labour" is never used in the text.
} 


\section{Articles}

\section{"Political Economy" or "Commerce in General"}

Montchrestien's mercantilism is not a theory which considers the wealth of the State as the main consequence of monetary abundance. What is decisive for him is agriculture (p. 78-9) which is just as much a moral as an economic factor: "From the time of our fathers [...] our very Nobility lived in the countryside. Since people have migrated to the towns, evil has increased ... idleness has developed". This is why the riches of France, "her wheat and her wines make her richer than all Perus" (p. 60). It is, in the final analysis, the "abundance of men" which is the real reason for this wealth (idem). Montchrestien thus underlines the quality of the workforce in this extremely rich kingdom, which is a "world" capable of surviving without other worlds; the town of Paris alone could even claim to be a "world"! If the source of wealth of the people of the kingdom comes from its size and the number of its subjects, it is thus natural to ask about the proper organisation of the division of labour in this world economy that is France. Certainly, Montchrestien never uses the term, division of labour, as was underlined above. He evokes "this public work, divided between the liberal arts and trade" (p. 73) which ought to be the object of "political foresight". Nothing is said about the commercial origins of this division; it is above all claimed that it cannot spontaneously regulate itself for the common good on account of the economic motivations
Sovereignty and Economy According

to Montchrestien and Cantillon

of men. This description of the economy is coherent with the idea that work must be instituted by the monarch. It is recommended that he use all the regulations possible to allow the liberal arts and trade to flourish: the "emulation" (p. 72) praised by Montchrestien should be used for the good of society. But if this emulation is left to its own devices, the author fears that it is entirely possible, given the sad state of industry in France, that the forces of competition could be more favourable to foreigners than to the subjects of the King. It seems that Montchrestien is fully aware of the importance of the division of labour and of emulation, but these two things cannot spontaneously contribute to the social good.

Indeed, the private economy is the model for the national economy and only a good government can make a good economy. Firstly, Montchrestien underlines that "private occupation makes public occupation" to assert that "good private government [...] is an example to public government" (p. 52). From this, we cannot simply deduct that political economy is nothing more than the art of the good management of the oikos which may be considered as the Kingdom of France, because Montchrestien is a Modern who does not present the Kingdom as such. For him, it is about defending conscious state interventionism in what were starting to be perceived as economic mechanisms ${ }^{27}$. This is assuredly novel. It should be possible to

\footnotetext{
${ }^{27}$ According to Gautier (2002, pp. 82-100), it is necessary to distinguish two different ways in which society is represented by many political thinkers from the end of the 17th Century and the 18th Century. For some, society is conceived of as a machine, organised by a social architect or a deux ex machina: Smith himself uses the watch analogy. For others, society is considered as an organism which develops independently of any human or divine intervention. In this framework, which can be qualified as a "spontaneous view of society" as opposed to a mechanistic view, society is no longer subjected to a teleological principle. Two models thus clash with each other: the machine mechanism on one hand and the vitality of the organism on the other (it goes without saying that the role of politics and the economy is different in the two models - see Deleule's (1979) commentary on Hume). We can understand why Hayek (1988) cites Ferguson as one of his inspirations: Ferguson's work is relevant to the NeoAustrian school in economics because he is undoubtedly a supporter of the organic view of society (see also Gautier's (1993, p. 72) commentary on Ferguson (1759)). It is moreover paradoxical that Clark's neoclassical theory, which is criticised by Veblen who invokes some convincing arguments from the end of the 19th Century, presents the social in a teleological framework, whereas the efficient defence of the market as a regulatory mechanism implies a spontaneous view of society.
} 


\section{Articles}

distinguish Montchrestien's mechanistic view of society, which supposes the existence of a "social architect", from a spontaneous view of society, characterised by the primacy given to emergent phenomena. Custom, which from this angle appears to be the very prototype of spontaneous phenomenon rather than a mechanistic system, is not at the centre of Montchrestien's theory.

The proper administration of markets and the correct management of the flow of money are a considerable part of Montchrestien's system, even if it cannot be forgotten that, for him, the wealth of the people is founded upon agriculture and, above all, men, meaning work. Political economy is thus not a science of the self-regulating market system: it simply represents the emergence of the notion of political economy as we understand it today. The economy as commerce is marked by a separation which keeps reappearing in an obsessive way. Indeed, there are two worlds of exchange which, for Montchrestien, cannot collide: the world of foreign trade places itself in opposition to the world of domestic trade $^{28}$. In this respect, we could not possibly qualify the author's reflections as simple "economic nationalism", unless we wanted to hide what we consider to be decisive in his work. Admittedly, as the money supply is considered to be a constant, Montchrestien often claims that foreign or external trade is a zero sum game. Yet his thoughts on the subject are more nuanced: he also notes that the different social relationships which characterise domestic and foreign trade ${ }^{29}$ are fundamentally different from the social relationships which characterise foreign trade. This latter is effectively understood as an arbitrary rule, inequality of trading relations and totally unjust laws, which cannot generate the gain from trade that is the main feature of domestic exchanges. The King's subjects are then, for the most part, all obliged to follow the same law and where the feeling of reciprocal goodwill is highly effective ${ }^{30}$. The economic nationalism that we sometimes think we detect in this text is the necessary result of the fact that competition between states is ferocious, hardly lending itself to soothing commentary.

"The commerce of inside" (p. 291) is considered to be "safer" and more widespread than "the commerce of outside", considered as "bigger, more renowned, riskier and susceptible to profits and losses". It is as if these two models of exchange structure the work of the author. On the one hand, we find a model of markets in which commerce

\footnotetext{
${ }^{28}$ Larrère (1992, p. 111-113) developed a thesis on the "Aristotelian structure of mercantilism" that we in part support. Indeed, below we highlight a specific mode of foreign trade which could benefit everyone. Certainly, Spector $(2003$, p. 305) rightly points out a passage in Montchrestien's work in which liquid metaphors seem to be the key to his system: "It is as if one is holding a vase of water in each hand, pouring liquid from one to the other. These are not simple merchants or agents of foreign merchants. All of them serve as pumps, sucking the blood from our people and selling it abroad" (p. 303). Montchrestien clearly regrets this loss of money for the State. But a strict Aristotelian structure of exchange should rest on the idea of the exchange of equivalents as if there was no possible profit to be made from it. Yet, as we see it, this idea that commerce is not systematically a zero sum game is perceived by Montchrestien. On the contrary, it is not so sure, as Spector claims (2003, p. 206), that morality is essentially a private thing for Montchrestien. In our opinion, Montchrestien does not isolate morality from the economy, as is proved by his comments regarding Censure.

29 The confusion of "internal" and "national" commerce is a recent phenomenon. One does not have to be the prisoner of retrospective illusion to speak of a "Nation-State" in the 17th Century, except to write a teleological history. Let us note moreover that the "nations" of the era were totally different from the idea of the nation as it was understood in France at the end of the $18^{\text {th }}$ Century. Indeed, the Kingdom of France, as Montchrestien described it, and as was obvious to readers of his time, is made up of people and, in certain cases, "nations" (such as the Angevine nation).

30 Montchrestien's hypothesis does not refer to the "state of nature" that was to become so widely accepted. Within the Kingdom, the monarch can transform the "multitude" into a "social body" because he is at once "Love" and the trustee of "Divine Authority". On the other hand, the state of nature does indeed exist between the kingdoms and republics which make up the world. Hence the question of jus gentium which is dealt with below.
} 


\section{Articles}

is subordinate to the social sphere, and trade embodies economic transactions and forms of social relationships corresponding to cultural value. Montchrestien writes a sentence which echoes an ancient commercial mentality: "It is said that one can never lose what the other cannot win. That is correct, especially with regard to trade. However, I would say that in trade that is carried out between citizens, there is no loss for the public" ( $p$. 303). Moreover, he invokes another side of the market in which "negative reciprocity" 31 dominates because the commercial partner does not belong to any pre-existing social community. The parties to the exchange are in a state of radical otherness, the relations between groups or individuals are not sufficiently durable to be instituted. It is also a particularity of the general equilibrium theory that it attempted to transform these asocial exchanges into a system profitable for all because it is based on the strict equality of the members of the community of exchange ${ }^{32}$. Montchrestien thus raises a sensitive issue that contemporary theory attempts to take into account. In addition, he foresees that unsymmetrical positions in the process of exchange are harmful from the collective point of view - another truly topical problem. For him, it is foreigners, or simply the laws of foreign states, which create the imbalance of trade which harms the subjects of the King of France. He observes that trade between France and Spain, on the other hand, was once mutually profitable (p. 302). In these ancient times, the wheat of France was exchanged against Spanish gold.
Sovereignty and Economy According

to Montchrestien and Cantillon

However, the Franco-Spanish trade of his day no longer seemed to bring reciprocal benefit. Consequently, he deplores "the unequal treatment that the Spanish receive in France and that the French receive in Spain with regard to the taxes levied on goods" (p. 351). Worse, he remarks that the English have the right to trade more freely than the Spanish! Rather surprising for a mercantilist, Montchrestien insists on the fact that genuine commercial reciprocity could be advantageous to all. If the French monarch could equalise the rights of his subjects and the rights of the Spaniards (p. 356) we could "supply them in abundance with the principal goods they need forty percent cheaper than they can procure them in Spain". Montchrestien considers that commercial reciprocity would be beneficial to the welfare of the Spanish since he perceived the possibility of gain resulting from trade. His belief reflects the development of a merchant society ${ }^{33}$ in the $17^{\text {th }}$ Century: we are no longer dealing with the ideal of a strict exchange of equivalents, the sole aim of which is to preserve the ancient phylia at the heart of the polis.

Montchrestien is nonetheless aware that the extension of commercial freedom that he demands is not necessarily advantageous from a fiscal point of view. With reference to the King of Spain and the French, he underlines, "He would in reality gain nothing but we would not lose anything either". He consequently calls for higher considerations of justice: "So long as all the provinces of France are freely open to Spain, why should the greatest and best of Spanish provinces be closed and forbidden to France?" Because commerce is regulated

\footnotetext{
31 The expression belongs to Sahlins (1972, p. 249).

32 The theoretical cost here consists in making hypotheses of central authority, which represent the return of society as a whole in the very functioning of the processes of exchange. This is surprising from the very point of view of methodological individualism.

${ }^{33}$ The "merchant society" we describe here is obviously to be distinguished from Polanyi's "market society"which developed in the $19^{\text {th }}$ Century (Polanyi, 1977, p. 12).
} 


\section{Articles}

by the jus gentium, he insists, commercial partners must have the same rights ${ }^{34}$. This is why we must explain the precise nature of this dual model of exchange. Could there not have been, for this author, a third possible model of exchange - the commerce of the jus gentium, where foreign transactions are profitable for all, even if the State does not necessarily gain extra benefit? According to this model, states guarantee the protection of those who participate in trade and the symmetry of commercial relationships. It is interesting to note that Montchrestien lambasts the lack of freedom that the King of Spain inflicts on his subjects whilst, on the other hand, he praises the French King who supports the universal jus gentium (p. 359) and "free trade". The qualifier, "free", should not however be taken literally: freedom here refers to a system of privileges granted by royal authority to merchants, giving them the means to trade freely $^{35}$. Our current "economic freedom" is in no way a given of Montchrestien's society. Similarly, all misinterpretation with regard to political freedom must be avoided. When Montchrestien defends France as the land of freedom, as he so often does, he means that the State frees any man who enters the territory from servility and that there are rights against what is arbitrary: the absolute monarch is by no means a despot ${ }^{36}$.

\section{"Mercantilism", Commerce and Money}

If forms of exchange are at the very heart of Montchrestien's work, whether with regard to the exchange of goods or to the exchange which takes place between the monarch and his subjects, it is more difficult to determine the role of money and prices. Although these issues are often debated in detail by the author, it is not clear how they are linked with the rest of his work which, on the contrary, seems to us to form a coherent system. If the question of sovereignty is central to Montchrestien's work, money does not necessarily occupy the key place that we sometimes allow it. Consequently, we do not share the idea according to which money is understood from a political point of view by all mercantilists ${ }^{37}$, contrary to an English political economy which, at the end of the 18th Century, was only political in name. Furthermore, we shall see how the "mercantilist" Cantillon separates sovereignty from money.

Montchrestien, using a purely economic line of reasoning, holds that the devaluation of monies is a worrying cause of social disorder since it erodes fixed income, impeding the normal course of business (p. 319-20). This conception of monetary phenomena can be even better understood as it is described by Cantillon (1755, p. 155 sq.). Examining the events of 1714, he explains that the

\footnotetext{
${ }^{34}$ Curiously, Billacois asks himself if Montchrestien had not read Grotius, yet the text he refers to, De jure pacis et belli, was not published until 1625 ! This work is dedicated to Louis XIII, Grotius having taken refuge in France. It would be better to ask, "Had Grotius read Montchrestien?"

35 Here, we are concerned with the "defensive capitalism" described by Commons (1924). It might seem odd that these "freedoms" are often the result of the creation of monopolies which benefit private individuals or companies. However, the reduction of arbitrary feudal rules created possibilities for capital. In this respect, Montchrestien's work is a reflection this new state of affairs. Commons considers that "the guilds were defensive capitalism" (p. 226). The "offensive stage" of capitalism" (p. 228) no longer needs these ancient monopolies, the existence of which was the precondition for the development of the defensive phase. The profits of the monopolies thus cease to be legitimate. On the contrary, the aim of the common law is to abolish private jurisdictions which run counter to the spirit of competition. Modern or "offensive" capitalism is thus a legal construction which forms part of a long drawn-out process of institutionalisation. For Commons, this does not mean that the pure ideal of competition is an intangible given of capitalism because the economic power of big companies and the development of credit money is what justified the interventionism of Roosevelt (Commons, 1934, p. 612).

${ }^{36}$ This was the reality of the Ancien Régime. For more on this topic, see Descimon and Guéry (1989, p. 215 and p. 222 ).

${ }^{37}$ See Servet (1977, p. 44 sq.) and Servet (1979).
} 


\section{Articles}

manipulations of the unit of account, although profitable to the King, can be detrimental to his subjects. Where Montchrestien only has a vague idea of a mechanism and of the perverse effects of wanting to stop it from functioning correctly, Cantillon makes a model of it. His analysis of Portugal's policy, the unintended and negative effects of which upset the harmony of the commercial mechanism (p. 144 sq.), is extremely revealing. Let us suppose that the King of this country wanted to make savings on the export of precious metals, in an artificial way, using prohibitions which cause "terror". The result would only be to make the price of highly-desired imported goods rise, encouraging law-breaking!

"There is no advantage to be gained from such a law; on the contrary, it will severely disadvantage Portugal since it causes even more money to leave the country than would be the case if such a law had never existed" (p. 145). There is in this the outline of a pure economic model which puts a price on risk and presents the lawbreaker as an "entrepreneur". It illustrates the perverse effects of interventionism, following a logic which was to have considerable future success. Nevertheless, with Cantillon, there is no system which rejects the principle of state intervention which, since then, has often been associated with a purely economic paradigm: "The export of the State's manufactured products must, so far as possible, be encouraged ${ }^{38 ",}$, he wrote (p. 129), similarly to Montchrestien. Criticising states such as France and Spain which "do not take into account in their policy the way in which trade would be advantageous" ( $p$. 133), Cantillon deplores the fact that "most
Sovereignty and Economy According

to Montchrestien and Cantillon

merchants in France and Spain who trade with the foreigner are rather agents of the foreign merchants than entrepreneurs trading on their own account" (p. 133, our italics). Montchrestien (p. 308-309) had already made such a criticism: "I have already said that we allowed our business to be looked after by the agents of foreign traders [...] Thus we became the agents of the agents"39. From the retrospective point of view that a supporter of economics as a human science might adopt, it might be argued that there is a rupture in the logic of Cantillon's work which may lead him to be considered as an author of transition between mercantilism and liberalism.

For Montchrestien and Cantillon, the key to monetary and financial stability is the balance of public finances. Cantillon (p. 167) is wellknown for his criticisms of John Law's system, the ultimate aim of which was to absorb the State's debt via an "abundance of fictitious and imaginary money". This causes the "same disadvantages as an increase of real money in circulation". Similarly, Montchrestien (1615, p. 259) had already held, not without some pathos, that the Royal debt must be reduced as much as possible since it serves as "a squadron of bloodsuckers on your people" ( $p$. 260). The Turkish model is, in this respect, an example of "good administration", on account of the proportionately small number of people operating in the system of public finance and of the "middle way" that one finds there (p. 322). Montchrestien, in a rather surprising way for a "mercantilist", underlines that the Ottoman sultan, an "absolute" monarch like the King to whom he is addressing his advice, tolerates the free movement of currencies in Cairo ${ }^{40}$.

\footnotetext{
${ }^{38}$ The "State" in this sense is not the State as we know it today. Cantillon uses this term to refer to a kingdom or the territories of a republic, as was common in his day.

${ }^{39}$ In addition, Montchrestien fears that the consequence of the presence of these young foreign agents ruled by their masters is that "The Republic is filled with mongrels" (p. 309), a "shame" amongst others (p. 208). We see to what extent Montchrestien's work amalgamates the categories that Cantillon on the contrary isolates so as to concentrate solely on the study of mechanisms.

40 Servet (1977, p. 51), however, cites Montchrestien who affirms, "Only he who is the architect of the Law can make law for monies" (p. 176, 1889 edition of the Traicté). Citations from different authors could support the hypothesis of the similar nature
} 


\section{Articles}

The political absolutism that is so praised by Montchrestien does not necessarily entail the monopoly to mint money. In removing money from this central position, Montchrestien may be seen as a particular kind of mercantilist. But, indeed, Cantillon is also a strange mercantilist, if mercantilism is above all an art which aims to obtain a trade surplus.

Actually, according to Cantillon (1755, p. 107), fluctuations in the money supply cannot affect the cycle of state power in the longterm: at best, the "able minister" can only "start the cycle off again" for states which seem to be governed by natural law. The same applies when excess wealth comes from "industrious inhabitants" rather than from the exploitation of local mines. Cantillon attempts to show all the advantages that can result from this tendency towards "industry". He recommends the adoption of an active policy in favour of "ample navigation" and "manufactured products that are sent abroad" (p. 101), since metallic wealth generated by conquest seems to him to be totally harmful (as shown by the case of Spain), contrary to a trade surplus ${ }^{41}$. Finally, legislating to allow the hoarding of this latter is, without doubt, the only lasting benefit, to the extent the State can thus keep the metal "for unforeseen emergencies" (p. 102) ${ }^{42}$. Cantillon even employs a sophisticated argument to show that the increase of the money supply does not simply cause a rise in prices but also a distortion of market prices so that, to use a contemporary expression, money is not neutral. Indeed, depending on whether one is far or remote from the source of the additional flow of money, whether one lives with a stable income or not, the increase in the flow of money produces different effects, resulting not only in the distortion of the original distribution of earnings but also in the modification of the very structure of global production (p. 92). This, moreover, is why Hayek's attention was drawn to this type of reasoning, which does not mask the complexity of the monetary processes at work in the economic process and which underlines the vanity of the policy of modifying the economic structure ${ }^{43}$. This is where we find a central difference with Montchrestien whose analysis concerning the means of fighting against the high cost of goods illustrates well his belief in the effectiveness of political action.

Pointing out that the Kingdom had to suffer the consequences of ever-increasing quantities of gold coming from the Americas which caused "the prices of all sorts of commodities to rise" (Montchrestien, 1615, p. 397), he asserts that "the essential value of merchandise is static [...] that nothing is expensive that was ever cheap" (p. 397). He recommends the simple application of existing laws to lower the price of goods, as if the issue was not the general level of prices but rather the level of certain relative prices essential for the livelihood of the people. In a very classical way, he considers it necessary for the State to fight against speculators by regulating the grain market so that prices can

of all discourses on money: "Whether they are about the sun, the prince or of gold, in all three cases, we have the image of a circular system in which the centre is fixed" (Servet, 1977, p. 49). Hence the centrality of money and of the king, entities which are closely linked. However, the Ottoman example given by Montchrestien does not clearly illustrate this link since, in this case, the sovereignty of the prince seems not to necessarily be exercised in relation to money. Does Montchrestien contradict himself here?

${ }^{41}$ See the virtuous case of England, p. 94 and p. 95 n1.

${ }^{42}$ At the beginning of the 20th Century, the gold standard was, in fact, a "managed gold standard", according to Irving Fisher who even suggests gold hoarding in order to prevent currency inflation from causing a worthless economic cycle and the consequent inflation of prices calling for their subsequent deflation.

${ }^{43}$ Hayek (1931). 


\section{Articles}

return to their previous level: "To conclude, it is only via this regulation (such as Your Majesty can establish and operate it in this Kingdom) that the price of merchandise and essential supplies can return to its original level" (p. 398). Montchrestien describes the inflationary phenomenon via the changes in the structure of relative prices which affects the division of income: certain social classes are more exposed than others to this process of price fluctuation. This can create injustice on account of the destablising character of speculation and the danger of excessive freedom in the circulation of grain: "Due to the transactions of a few, an entire Province can end up starving" (p. 400). Our inventor of political economy thus contributed to the debate that would last until the end of the $18^{\text {th }}$ Century. Montchrestien perhaps stands out when he underlines that the asymmetry of trade, due to the unequal distribution of wealth within the Kingdom itself (p. 400-401) makes commerce harmful, although in the normal course of events, when it is well-managed, it contributes to the prosperity of all.

He thus suggests that the King must "first order that those who accumulate grain (and harvest all the fields in a country without selling the grain to the people) should be forbidden from doing so" (p. 398). Therefore, these little market-runners [...] monopolists of basic essentials, all those who cause prices to rise everywhere they operate, must be suffocated. Those who devour all the sustenance and food of the people are true leeches" (p. 399). Cantillon, on the other hand, in no way sees Montchrestien's "marketrunners" as dangerous pests, capable of harming the processes which allow economic balance to be established. They are rather seen as social categories who, living under
Sovereignty and Economy According

to Montchrestien and Cantillon

the weight of incertitude ("entrepreneurs live with a risky income" (Cantillon, 1755, p. 31)), pay the price of the establishment of a social order in which the dominant classes - "people [...] who live with a fixed income" - set the level and the structure of overall spending. He even goes so far as to divide the "State" into two classes - entrepreneurs and non-entrepreneurs - and he notes, in a rather hypermodern way, that "thieves are (forming a class) of entrepreneurs" (p. 32). This subordinated class of "entrepreneurs" is permanently exposed to "bankruptcy" as the necessary consequence of a market economy, the effectiveness of which is de facto superior to a planned economy. Of course, Cantillon does not make this point quite so explicitly but we simply wish to highlight the structure of his reasoning. It is no coincidence if Austrian economists, particularly those of the most recent school, have placed so much emphasis on the role of the entrepreneur in the market process: as capitalism has developed, the crucial role of arbitration and of speculation has become central.

On the other hand, whereas a coherent analysis of market processes or of economic equilibrium has no place in the Traicté, labor $^{44}$ occupies a key position. He explains that in order to face foreign competition, the workforce must be educated. Political economy is mostly a policy for the education of man. Consequently, Montchrestien is convinced that "no animal in the world is born more stupid than man. But, in a few short years, he can be made capable of great things. Whosoever can make something good out of this living tool [...] can glory in the fact that he has made the best of the economy and government" (Montchrestien, 1615, p. 61). He recalls how the Romans reportedly

\footnotetext{
${ }^{44}$ We do not wish to suggest here that there is no other form of theorisation concerning money, which seems to us to be a minor issue in Montchrestien's logic. This is even clearer for the analysis of market mechanisms: there is no discussion of the Market in his work but rather highly logical, relevant and empirically rich reflections on the functioning of markets.
} 


\section{Articles}

placed much importance on the education of their servants. Finally, he deduces that the chronic lack of employment in the Kingdom is thus due to a lack of qualifications (p. 612) and that it is for the good of the public that the poor should be obliged to work ( $p$. 62-3). The correct policy with relation to the "employment of men" is, consequently, to imitate the English and the Dutch who had once learnt from us (p. 119). He applauds the fact that, in Switzerland and Germany, "there is hardly a bourg in which the Lord does not finance a few colleges in order to instruct his poor subjects in the liberal arts and in the mechanical trades" (p. 120). It is thus necessary to follow the Dutch example of "schools" (p. 121). Even if these places are most certainly aimed at the "assistance of the poor" (p. 122), Montchrestien underlines the fact that the Dutch system also places emphasis on apprenticeship. In this way, the "common good" (p. 119) is achieved through the fact that the poor are no longer "dependent on the State" (p. 122).

Montchrestien's arguments are novel: this way of thinking about work was taken up by Colbert, in other words, well after 1615 . It would thus be possible to use the central place given to work to redefine the concept of mercantilism. For Montchrestien, if many nations were once, in a way, the "pupils" of the French, by his day it was the French who had been overcome by external competition and who should become the pupils: "As for everything else, the place has already been taken. If we want to attend the theatre, it must be as spectators since we are incapable of getting up on stage to act. All the roles have already been allocated to the people who know how to play them best (p. 346). The pupils who have become our teachers are chiefly the English (p. 99). He is not just concerned about that fact that the English have overcome their technical backwardness, thus competing with the people of France, but he also worries about the possible consequences of the King's decision to allow English capital to build a factory (p. 100) given that the English do not use the work of the French for the latter's own good (p. 101). Montchrestien does not use any of the concepts which have become indispensable to many economists since the Marginalist Revolution, such as equilibrium or tendency towards equilibrium. The visible hand of the monarch is seen as a condition of the economy, the correct functioning of which depends on politics. He upholds the idea that the economy is politically constituted. In this, he is totally modern, inaugurating an authentic quest for knowledge, even if his idea does not form part of the mainstream portrayals of what scientific knowledge of the economy should be.

For Cantillon, the visible hand of State is not a necessary precondition of an economic society, since he shows the possibility of the emergence of a kind of social order independent of politics, i.e he demonstrates the possibility of invisible hand. But, as the author of the transition from a merchant to a market society, he shares the typically mercantilist fear of foreign competition. Cantillon stands half-way between the usual mercantilist theses and liberal theses. He approves of royal interventions which aim to boost manufacturing, thus preventing monetary wealth from escaping abroad. The rule of the "best market" cannot be adopted, otherwise the Dutch would be "the only carriers in Europe" (Cantillon, 1755, p. 132), which means that outside the borders of a given "State" be it a republic or a kingdom - spontaneous market mechanisms are not efficient. With regard to kingdoms which can claim to be self-sufficient, such as England or France, he writes, "They must not allow the falling off of their own articles and manufactures nor become dependent on the foreigner, still less 


\section{Articles}

allow their money to be taken away for that purpose (p. 131). Here, Cantillon is very close to Montchrestien. Cantillon, one of those who prefigured the "invisible hand", calls for the very visible hand of politics to "encourage, as far as possible, the exportation of the articles and manufactures of the State" because "the increase in the quantity of silver circulating in a state gives it great advantages in foreign trade so long as this abundance of money lasts" (p. 129). This state of affairs gives birth to a cycle: the abundance which reigns in the kingdom produces contradictory forces which prompt a return to a certain equilibrium. All occurs as if the wisdom of the economist could only ensure that the State can benefit from an advantage during the only transitory period determined by two points of equilibrium.

The issue of mass poverty that lies behind many of Montchrestien's and Cantillon's proposals is particularly important ${ }^{45}$ : the modern era is that of the poor laws, the financial cost of which is well-known. Montchrestien takes part in a debate that was particularly lively in the $17^{\text {th }}$ Century and which only ended in the $19^{\text {th }}$ Century (at least in that particular form). In this respect, Polanyi (1944) shows the impact of Townsend's text, the Dissertation on the Poor Laws ${ }^{46}$, written in 1786, in which a biological portrayal of society is a means of radically emancipating the economy from politics. Smith's political economy, impregnated with moral discourse and all kinds of cautionary notes did not herald the ideology of the market society ( $p$.
Sovereignty and Economy According

to Montchrestien and Cantillon

115). The Dissertation, using the example of a Pacific island populated by goats and dogs - prey and their predators - explains that a natural equilibrium exists. Should any species proliferate beyond a sustainable level, the excessive mortality resulting from the scarcity of resources will be the key to a process of adjustment ${ }^{47}$. So Polanyi can write that "The economic society had emerged as distinct from the political state" (p. 115). He underlines the lack of empirical evidence to support this fable. Yet, this is not the main point. The fable relies on the curious notion of identification rather than metaphor: "Hobbes had argued the need for a despot because men were like beasts; Townsend insisted that they were actually beasts and that, precisely for that reason, only a minimum of government was required" (Polanyi italics, p. 114). Townsend's model animalises man: it assumes that competition by all against all allows the development of economic and thus social harmony, without politics being necessary.

Montchrestien's theory is the total opposite of that of Townsend, on account of his peculiar conception of sociability and his demonstration of the necessity of the visible hand of the King to be properly used. An important dimension of political economy is, in that respect, the necessary protection of economic agents by political power, since foreign trade, although unpredictable and dangerous, is indispensable to the common good. This is not just about protecting the Kingdom from the foreign competition which

\footnotetext{
${ }^{45}$ Note the importance given to man whose work is the source of wealth: from this point of view, it is man's lack of education which is the cause of disorder, such as underemployment. The problem is fundamentally political: the King has not yet taken the correct measures to correct the "dysfunctional" economy. This is why we do not accept Perrot's idea (1992, pp. 145-146) according to which Montchrestien generally holds that the poverty of the kingdom is the result of the "corruption" of "lazy stomachs", even if some citations may encourage one to regard Montchrestien more as a moralistic writer than as a scholar of political economy.

${ }^{46} \mathrm{http}: / /$ socserv.mcmaster.ca/econ/ugcm/3॥3/townsend/poorlaw.html

${ }_{47}$ Therefore, the proliferation of one species over another is only a short-term phenomenon. Townsend himself transposes the story to human society: "Thus a new kind of balance was established. The weakest of both species were among the first to pay the debt of nature; the most active and vigorous preserved their lives. It is the quantity of food which regulates the numbers of the human species" (quoted by Polanyi (1944, p. 113). Thus, state intervention is deemed unnecessary.
} 


\section{Articles}

reduces employment (p. 104), but also about promoting a genuine policy which aims to substitute imports with domestic production. To the objection that the quest for autarchy is a cause of war, Montchrestien responds that it is the rest of the world that needs France more than France needs the world: the size of the population of the kingdom at this time should not lead us to consider this proposition as absurd. Montchrestien is nonetheless aware that the public benefit resulting from the employment of the poor can a priori be to the detriment of affordable supplies. But "the benefit to the public is more important than any other advantages that may be advanced" (p. 326). He does not however just develop this argument concerning social stability, so necessary to the prosperity of the Kingdom. $\mathrm{He}$ also explains that the development of domestic production will allow prices to fall as low as possible. The argument has some coherence, aside from its preemptory rhetoric, since it involves the recognition of a certain length of time necessary to the development of this production that can alone provide temporary protection and allow the workforce to be well-educated. It should be noted that he does not make a dogma out of protection; its value is judged according to the circumstances.

State control should go further and determine the correct amount of production. Here, mercantilism seems to be a doctrine generalising the customs of medieval towns to territories incomparably more vast. The market as a process of price fixing and the determination of optimal quantities is strangely absent. Montchrestien, dealing with the issue of the possible excess of production and of the necessary profits of artificers writes, "The wise ruler must carefully invent the means to govern, finding the right balance between too little and too great" (Montchrestien, 1615, p. 127). Once again, the contrast is striking between how this issue is dealt with in the Essai. Cantillon (1775, p. 28) shows that "the circulation and the exchange of goods and merchandise, as well as their production, are carried out in Europe by entrepreneurs, and at a risk" because the market mechanisms can produce order from parts of the economy which may at first seem incompatible. Indeed, trade-off carried out by entrepreneurs allows consumption and production to be adjusted as best as possible in the social interest, something which politics cannot do just as well. It is moreover this way of thinking about equilibrium which leads Cantillon to conclude that deliberate action to educate the workforce is generally useless (p. 14-15). He believes that the allocation of labour occurs spontaneously. He explains, "If the King of France were to send one hundred thousand of his subjects to Holland to learn seafaring, they would be useless on their return if no more vessels were sent to sea than before". Nonetheless, Cantillon's arguments are more nuanced and, in some ways, reveal themselves to be mercantilist. When he takes into account the consequences of foreign competition in his analysis of the internal equilibrium of the kingdom, he concludes that the savings made on imports thanks to a more skilled workforce (which would result from royal intervention) is a good thing for the State (p. 15). Cantillon's model is still essentially different from that of Montchrestien (1615) who often considers the so-called "natural economy" as a source of the political economy. In the same passage concerning the "wise ruler" (p. 27), he writes, "It must imitate nature which never lacks anything essential and which never produces anything superfluous". Thus, the monarch's policy must lead the dysfunctional economy, in the very words of Montchrestien, back to "nature". The meaning of the adjective "nature" should not confuse the reader. This model of domestic 


\section{Articles}

life of course evokes the "middle way" of the great Turkish sultan. The political economy thus condemns the excessive consumption of wealth which must be embedded in moral considerations. The economy is the result of a policy constrained by moral designs. Morality and the need for the accumulation of metal join together harmoniously since there is a trade deficit with the Levant on account of the elite's weakness for luxury, the "public plague and the ruin of monarchies!" (p. 361).

The above arguments have used the concept of mercantilism, yet this concept is difficult to handle and often throws more shadow than light on the subject once a detailed analysis of authors generally classified as mercantilists is required ${ }^{48}$. It is on the other hand possible to argue that, on a quite general level, mercantilism can be defined as the recognition that "the economy is henceforth the means of exercising power and its very foundation"49. In this sense, it is true that common ground can be found between those who support the doctrine of "gentle commerce" and the mercantilists, these lucid thinkers who, early on, did not conceive of the economy as a peaceful sphere. But, at this level of generality, the place of money in mercantilist discourse and its relationship with sovereignty is not clear. Moreover, the thesis of the "Aristotelian structure" of mercantilist exchange ${ }^{50}$, which is evidently wide-reaching, is not capable of highlighting the full originality of Montchrestien who does not neglect the possible mutual profits that may be gained from exchange.
Sovereignty and Economy According

to Montchrestien and Cantillon

\section{Conclusion: The Strength of the Traicté and the Essai}

The invention of political economy involved the discovery of the economy as a legitimate concern of the state, contrary to the Ancients. It meant no longer thinking about good economic management as a means of maximising the income of the estate or the city, but rather about promoting a policy which would aim to increase the wealth of the people. In this sense, the wealth of the State is a mere consequence of the wealth of the people. Political economy is not a science of the market since the market is not the main element of the economy: there are only markets which may be governed by rules, allowing the monarch to act for the benefit of all. Current trends thus do not help us understand an author who is so attached to the issue of sovereignty. This new art, promoted by Montchrestien (p. 406), is the establishment of good government, which involves moral considerations which affect the organisation of markets. These are considerations which may seem as ideological as they are normative and, consequently, non-scientific. On the contrary, Cantillon's work prefigures purely economic paradigm on account of the extremely wide definition that he gives of the entrepreneur and due to a theory of equilibrium which underestimates, without systematically denying, the positivity of economic policy. Admittedly, his proposed state intervention with regard to foreign trade can be used to claim that his work is archaic, but this would ignore the fact that all ruptures must be understood in context. More generally, Cantillon seems to us to have effectively inaugurated the mainstream spirit

\footnotetext{
${ }^{48}$ As Marquer notes (2003, p. 373-374).

${ }^{49}$ See Spector (2003, p. 302 et p. 308-309).

50 Larrère's thesis was taken up by Spector (2003) who, even if she correctly underlines the "profound changes" of the "Aristotelian" schema, does not fully appreciate all of its consequences.
} 


\section{Articles}

of economics, which does not define itself as a field but rather as a science of choice, independent of the existence of markets.

It would nonetheless be wrong to judge the interest of Montchrestien's work from the sole point of view of the current economic thought. Moreover, it is doubtful that our knowledge is really free from ideological considerations. Should it not also be remembered that many economists are now divided on the banishment of powers and institutions which made the foundation of economics possible? Yet, the hope of reducing phenomena relating to power and authority to pure economic reason seems questionable ${ }^{51}$. This is why the reading of ancient texts can encourage some distance to be taken from a certain number of obvious facts. If an author like Montchrestien contributed to the creation of a genuinely novel kind of discourse, it is because he considers that men, the source of wealth, should be the principal concern of the government. Certainly, Montchrestien seems to belong to a time long past when he echoes the ancient practices of the medieval guilds, suggesting they be applied at the level of an entire kingdom. Far from Foucault's conception of liberalism, Montchrestien does not provide the most economically efficient technique for the ruling of men $^{52}$.

What is decisive for judging the modernity of a policy is not necessarily its liberal character but the fact that the economy is the object of policy. It is true that Montchrestien considers markets as subordinate elements since they are only the economic elements of policy. Here, we are far removed from what was developed in the $18^{\text {th }}$ Century, with the birth of classical political economy, since, as Foucault writes, liberal modernity aims to show that there is "an incompatibility of principle between the optimal functioning of the economic process and the maximisation of governmental procedures"53. From this perspective, Cantillon is an author of central importance since he shows how the economy can regulate itself. Good knowledge of Commerce in general can only allow the state and its people to enjoy the real but temporary benefits of trade, due to the mechanisms which push towards the spontaneous creation of social order. For this pivotal author, economic policy is thus not systematically negative but is subordinate to long-term equilibrium which is spontaneously determined, resulting from the essential exteriority of politics with relation to the economy.

The world presented by Montchrestien is, in principle, different: political economy thus does not herald a liberal way of thinking. Nevertheless, this does not mean that his project is not modern because his modernity, as we have seen, is based on the systematic portrayal of the economy as lying in the public domain. But this does not imply that his political economy, as a way of governing men, is based on the notion of the autonomy of the economy. It is for this reason that Perrot's (1992, pp. 90-91) analysis is questionable: he concludes that economists "over the course of two centuries" have provided the "hypothesis of spontaneous regulation". Montchrestien

\footnotetext{
${ }^{51}$ Elster (1989) claims that reductionisms fail to explain social norms. In particular, he refers to a reductionism in vogue amongst many economists according to whom norms can be viewed as a system resolving market failures. Yet, firstly, many norms damage the welfare of all and, secondly, it is not known how the social advantages of norms may be perpetuated.

52 See Foucault (1989, p. 112) who characterises "liberal thought" by the hypothesis of "a society which finds itself in a complex relationship with exteriority and interiority with the State [...] The idea of society is what allows a technology of government to be developed, starting from the principle that it is already, in itself, "too much" and "in excess". The important place which Foucault gives to the ordoliberalism of the Fribourg School should be noted (pp. 117-118).

${ }^{53}$ See Foucault $(1989$, p. 114). It is in this sense that Foucault considers that the 18th Century economists depart from mercantilism (p. 115).
} 


\section{Articles}

ought to be excluded from his analysis ${ }^{54}$. This historian also refers to "Montchrestien's axiom" according to which "everyone wants to be rich" 55 . This leads him to write, "This claim is so obvious that it is pointless to write it down". Yet, for us, it does not seem possible to link this "axiom" to the hypothesis of the auto-regulation of the economy in any logical way. Our hypothesis is that this desire for wealth does not have the same meaning in the emerging political economy of the 17th Century or in the economic discourse which developed in the 18th Century.

First of all, this assertion of the selfish motivations of mankind, a key element of mainstream thought, cannot be understood in a transhistorical way. Marx ${ }^{56}$ observes that, as an individual, Brutus knew how to lend his money at the best rate possible; as for the Romans, "The question is always which mode of property creates the best citizens". This example serves to show that the desire to be rich can form part of very particular institutional systems, making it impossible to draw precise conclusions for a general analysis. Is it therefore possible, without great risk, to establish continuity between Montchrestien's discourse on human nature and Hume's economic anthropology? Quesnay's claim, underlined by Perrot,
Sovereignty and Economy According

to Montchrestien and Cantillon

according to which the conflict of individual interests does not necessarily lead to their destruction since "by necessity, they both strive for general well-being" 57 , only displaces the problem: what is indeed the very nature of this alleged necessity?

In this respect, as was mentioned above, Montchrestien follows a way of thought which emphasises the mechanistic over the spontaneous but suggests that economy is not an autonomous category of thought. But if the Market ${ }^{58}$, or even the more or less metaphorical uses of the invisible hand, do not mark Montchrestien's economy, competition lies at the heart of his work. This competition, in the sense that we now qualify as international, is thus, before markets themselves, a striking characteristic of economy. Actually, most markets are political codifications of competitive flux. It is moreover this crucial characteristic of competition, in its most lethal sense, which legitimates this model of triple commerce that we have mentioned, which is itself the product of a model of double exchange. The natural sociability of the citizens of the kingdom indeed determines the forms of exchange from which we can all benefit, contrary to external trade which is nothing but a refraction of a war model. Montchrestien nonetheless considers that the

\footnotetext{
54 Something which Perrot does not do (p. 63). This is why the issue of the "selfish interest" of the individual and that of the "regulation of the collectivity" are not elements that can be considered as the two bases of Montchrestien's theory (as Perrot suggests (1992, p. 89)). Montchrestien's idea is not that of the "invisible hand" and does not involve a conceptual distinction between civil society and the State. As Foucault (1989, p. 113) underlines, "Rather than making the distinction between the State and civil society an all-purpose explanation which allows all concrete systems to be questioned, one should try to see a form of schematisation common to the particular technology of government".

55 The Traicté, cited by Perrot (1992, p. 91, n. 79).

${ }^{56}$ Marx (1857-1858, p. 18) writes: "Do we never find in antiquity an inquiry into which form of landed property etc. is the most productive and creates the greatest wealth? Wealth does not appear as the aim of production, although Cato may well investigate which manner of cultivating a field brings the greatest rewards, and Brutus may even lend out his money at the best rates of interest".

${ }^{57}$ Quesnay, Second dialogue sur les artisans, cited by Perrot (1992, p. 91, n. 79).

${ }^{58}$ Ancient markets and the "Market" should indeed be differentiated. The Market is a principle of organisation of economic and social life according to which a network of markets is capable of regulating social reproduction. These markets are said to be "self-regulating" although, in reality, this self-regulation represents more the social ideal which legitimates these markets than the reality of self-regulation which is often chaotic or catastrophic. Thus, the Market is a cultural fiction which has the capacity of structuring empirical economies.
} 


\section{Articles}

application of the jus gentium could render external trade beneficial, provided that the imbalance of positions, which result from state policies, is eliminated. But it is clear that these kinds of benefits presuppose a prior political agreement. Montchrestien thus contributes to characterising the economy as political. The strength of his work and the reason why it is still relevant is that the economy and markets are presented as objects of political considerations which are essential to their very existence. Markets are expressions of sovereignty, political codifications of the flux of global competition, themselves instituted by states ${ }^{59}$.

Re-reading Montchrestien is thus interesting at a time when a variant of the postmodernist approach of Hardt and Negri (2000, p. 98), invites us to forget European-style "territorial sovereignty", which is supposedly dead, and relegates the Traicté to an antiquated past. From a theoretical and practical point of view, we should place ourselves on the level of 'Empire', as 'the political subject that effectively regulates these global exchanges, the sovereign power that governs the world" (p. 11). The legal model which allows the full realisation of Empire is to be found in the American constitution. With relation to European history and ideology, the advent of such an 'Empire' marks a rupture: this is not a place which heralds the end of the centreperipheral opposition. The development of a form of sovereignty which is not identified with any particular territory, such as the American federal model, heralds the death of the omnipotent territorial Nation-State. Exit then Bodin's European-style sovereignty, "the absolute and eternal power of a republic" which much inspired Montchrestien. For Hardt and Negri, it is not about making an apology for the Empire but, noting its emergence, putting oneself at its level in order to counter it. National or state entities are thus outdated. This is considered as a sign of progress since these entities would only have placed too many controls on the real driving force behind history - the "multitude"60. It would thus become impossible to rely on the idea of the nation as a people politically organised to prevent the development of the so-called Empire.

From this point of view, the "economic nationalism" which is often attributed to Montchrestien would thus be the reason to definitively relegate his book to an antiquated past. Yet, set against these postmodern claims, the relevance of Montchrestien's work is striking. He conceives of the political creation of markets in the framework of general anthropology and a fine analysis of trade where three strong models can be seen. It is the strength of such reasoning to show the political conditions of the constitution of markets which are all too often ignored. Montchrestien unveils another dimension of economic modernity which is still relevant the recognition that there can be no economy without sovereignty, except when imagining the antagonistic trend of modernity which dreams of the market self-regulation and which fulfills the wishes of the Empire of Capital. In this Empire, the "companies, on account of their size, have necessarily led to the creation of institutions capable of placing themselves at the centre of nations, as in the decreasingly virtual international sphere" (Guéry, 2005a, p. 41). Yet, the fundamental point which leads us to disagree with Hardt and Negri is that there can be no Empire of Capital without a

\footnotetext{
59 This idea is a personal interpretation of the work of French economist Michel Henochsberg (1946-2016), who is infortunately not read enough : see Henochsberg (2001).

60 Our point of view conflicts with that of Hardt and Negri who, ignoring all considerations of sovereignty and phophetising the end of nations, states and public controls, celebrate the liberating force of networks.
} 


\section{Articles}

State which carries this Empire. Hence, our uncertain times are those of an American hegemony which, following the British Empire's dream, aims to achieve global domination as much as by force as by consent. We are also witnessing the emergence of imperial counterprojects in Europe and in Asia. But our times are also those of the difficult construction of rules which can embody the jus gentium. Finally, our times are also those of nations, which have continued to an increase in numbers since the end of the last century, creating intractable problems with regard to the relationship between the economy and politics. But this difficulty is none other than that of democracy that the old technocratic ideal offers to reduce yet more.

We are not so far from Montchrestien here, even if a little over a century and a half after the publication of the Traicté, the people themselves erase this verticality of the monarch in favour of national sovereignty ${ }^{61}$. Evidently, this new political construction is divided by social differentiations which have economic consequences. Organising the people politically does not mean abolishing the tension which, according to Finley (1983), is the very invention of politics. In other words, politics is the instituted war between the common people and the powerful who often claimed to embody the common good in the name of the people. The technocratic dream, which involves the decline of popular sovereignty in favour of capitalist sovereignty, is nothing new and does not justify the postmodern position. From this point of view, there is the problem of the transfer of sovereignty towards a group which takes responsibility for the conduct of business under the pretext that the people are incompetent. In these conditions, a certain kind of economy
Sovereignty and Economy According

to Montchrestien and Cantillon

subordinates politics, laden with all kinds of vice, in favour of a very peculiar political project which promotes the proliferation of rules to avoid the very principle of political action, judged arbitrary and thus ineffective. The wisdom of Cantillon is, on the contrary, not to push too far his liberal intuitions concerning the autonomy of the economy. Therefore, he does not deny that politics may play a role in creating economic efficiency. However, does the difference between classical liberalism and some of its contemporary manifestations not actually result from the rise of this "esprit de système" which distances the theoretician from the necessary test of reality?

\section{References}

Andreau (1998), «Le cens, évaluation et monnaie dans l'Antiquité», pp. 213-250 in Aglietta M. et Orléan A. eds., (1998), La monnaie souveraine, Paris, Odile Jacob.

Arendt H., (1958) The Human Condition, Chicago, University of Chicago Press, 1958. Billoret J-L, (1989) “ Le circuit et l'équilibre de Boisguilbert dans le courant de l'analyse économique ", pp. 59-81 in Boisguilbert parmi nous, Paris, INED, 1989.

Cantillon R., (1755), Essai sur la nature du commerce en général, 1952 (Paris : INED, 1997).

Commons J. R., (1924) Legal Foundations of Capitalism, New-York, Mc Millan.

Commons J. R., (1934) Institutionnal Economics, Volume 1, New Brunswick \& New Jersey, Transaction Publishers, 1990.

Elster J., (1989) The cement of society - $A$ study of social order, Cambridge Cambridge University Press.

Billoret J-L, (1989) “ Le circuit et l'équilibre de Boisguilbert dans le courant de l'analyse

\footnotetext{
61 The nation thus becomes the political organisation of people according to a democratic structure. Often, the use of the word nation is imprecise. For some people, it refers to the "natives", as if two centuries of democratic modernity had not transformed the term to create something other than the "nations " of the Ancien Régime.
} 
économique ", pp. 59-81 dans Boisguilbert parmi nous, Paris, INED, 1989.

Constant B., (1819) " De la liberté des anciens comparée à celle des modernes ", in Ecrits politiques, Gallimard, 1997.

Deleule D., (1979) Hume et la naissance du libéralisme économique, Paris, Aubier.

Deleule D., (2001) " Anthropologie et économie chez Hume : la formation de la société civile ", dans C. Gautier ed., Hume et le concept de société civile, pp. 19-47, Paris, PUF.

Descimon et Guéry (1989) " Un Etat des temps modernes ", p. 209- p. 513 dans A. Burguière et $\mathrm{J}$. Revel eds., Histoire de France, volume La longue durée de l'Etat, Paris, Seuil, 2000.

Ferguson A., (1759) An Essay on the History of Civil Society, edited with a introduction by Duncan Forbes, Edinburg, University Edinburg Press, 1966.

Finley M. I., (1983) Politics in the Ancient World, Cambridge University Press, Cambridge.

Foucault M., (1989) Résumé de cours au Collège de France (1970-1982), Paris, Julliard.

Gautier C., (1993) L'invention de la société civile, Paris, PUF.

Gautier C., (2002) Société civile et sciences de la société, Note de synthèse pour l'habilitation à diriger les recherches en philosophie, Paris 10.

Grenier J-Y, (1996) L'économie d'Ancien Régime, Paris, Albin Michel.

Guéry A., (2003) " Nourrir le peuple échanges et marchés d'Ancien Régime ", Colloque de l'Association Charles Gide pour l'étude de la pensée économique - Histoire des représentations du marché, Grenoble.
Guéry A., (2005a) " L'empire du capital ", pp. 31-41, Rue Descartes, 49, mai.

Guéry A., (2005b) " Les historiens, les marchés et le marché", pp. 786-802, dans G. Bensimon ed., Histoire des représentations du marché, Paris, Michel Houdiard Editeur.

Foucault M., (1989) Résumé de cours au Collège de France 1970-1982, Paris, Julliard. Gautier C., (1993) L'invention de la société civile, Paris, PUF.

Gautier C., (2002) Société civile et sciences de la société, Note de synthèse pour l'habilitation à diriger les recherches en philosophie, University of Paris X.

Hayek F. A., (1931) Price and production, London, Routledge and Sons.

Hayek F. A., (1988) The fatal conceit - the errors of socialism, Routeledge, London and New York.

Henochsberg, M. (2001) La place du marché, Paris, Denoël

Kantorowicz E., (1957) The King's two Bodies - A Study in Mediaeval Political Theology, Princeton University Press, 1997.

Hardt M., Negri A., (2000) Empire, Cambridge, Harvard University Press.

Larrère C., (1992) L'invention de l'économie au XVIllième siècle, Paris, PUF.

Mac Donald S. (1966), " Aspects moderne des théories économiques de Boisguilbert ", pp. 101-119, dans Pierre de Boisguilbert ou la naissance de l'économie politique, tome 1 , collectif, Paris, INED, 1966.

Marquer E., (2003) «Les controverses à propos de la nature du commerce chez les premiers mercantilistes anglais", Revue de Métaphysique et de morale, 3 , septembre, pp. 365-377.

Marx K., (1857-1858) The Grundrisse, NOTEBOOK IV, mid-December 1857- 22 January 1858 (http://www.marxists.org/ 


\section{Articles}

archive/marx/works/1857/grundrisse/ch09. $\mathrm{htm})$

Montchrestien A., (1615) Traicté de l'œconomie politique, introduction by par $\mathrm{F}$. Billacois, Librairie Droz, Genève, 1999.

Polanyi K., (1944) The Great Transformation - the political and economic origins of our time, foreword by R. Maclver, Boston, Beacon Press.

Polanyi K., (1957) "The Economy as Instituted Process", in K. Polanyi, C. M. Arensberg, \& H. W. Pearson, Trade and Market in the Early Empires, Chicago, Gateway. Perrot J-C, (1992) Une histoire intellectuelle de l'économie politique, Paris, Editions de I'EHESS.
Sovereignty and Economy According

to Montchrestien and Cantillon

Polanyi K., (1977) The Livelihood, of man, New York, Academic Press.

Sahlins M. D., (1972) Stone Age Economics, Chicago: Aldine.

Servet J-M., (1977) " Les figures du troc du XVlième siècle au XIX siècle ", Analyse, Epistémologie, Histoire, 12.

Servet J-M., (1979) «Le Prince masqué : Formation de l'économie politique et occultation du politique», Procès, 4, pp. 154-184.

Spector C., (2003) «Le concept de mercantilisme», Revue de Métaphysique et de morale, 3, septembre, pp. 289-309.

Zemon Davis N., (2000) The Gift in Sixteenth-Century France, University of Wisconsin Press. 